\title{
Pseudoexfoliation syndrome at a Singapore eye
} \section{clinic}

Jason Kian Seng Lee Elizabeth Poh Ying Wong Su Ling Ho

National Healthcare Group Eye Institute, Tan Tock Seng Hospital, Singapore
Correspondence: Jason Kian Seng Lee National Healthcare Group Eye Institute, Tan Tock Seng Hospital, II, Jalan Tan

Tock Seng, Singapore 308433

Tel +65 63577726

Fax +6563578675

Email jason_ks_lee@ttsh.com.sg
This article was published in the following Dove Press journal:

Clinical Ophthalmology

3 September 2015

Number of times this article has been viewed

Background: The purpose of this study was to investigate the demographics of pseudoexfoliation syndrome (PXF) and pseudoexfoliative glaucoma (PXG) in a Singapore hospital eye outpatient clinic.

Methods: A retrospective study of 93 consecutive patients (146 eyes) with PXF was undertaken by a single ophthalmologist over a period of 37 months (July 1, 2006, to July 31, 2009).

Results: Ninety-three (2.8\%) of 3,297 patients seen during the study period were diagnosed with PXF. Forty-three (46.2\%) of the 93 PXF patients were male. Indians were 5.04 times more likely to develop PXF than Chinese $(P<0.001,95 \%$ confidence interval 3.05-8.33), while Malays were 2.22 times more likely to develop PXF as compared with Chinese $(P=0.029,95 \%$ CI 1.08-4.55). Twenty-two (23.7\%) of the 93 PXF patients had PXG at the time of diagnosis. There was no statistically significant difference in mean age between PXF and PXG patients. There was a larger proportion of males with PXG than females $(P<0.001)$.

Conclusion: PXF is not infrequent in elderly Singapore eye clinic patients, and is more likely to occur in Indians than in Chinese. In the Singapore eye clinic setting, males may be more likely to develop PXG, although larger studies will be required to confirm this.

Keywords: exfoliation syndrome, pseudoexfoliation syndrome, exfoliation glaucoma, glaucoma capsulare

\section{Introduction}

Pseudoexfoliation syndrome (PXF) is thought to be an ocular manifestation of a systemic extracellular matrix disorder characterized by accumulation of fibrillar material in tissues, including ocular tissues. ${ }^{1-5}$ It is characterized by the presence of small, white pseudoexfoliative material in the anterior segment, predominantly on the pupillary margin and anterior lens capsule. ${ }^{6}$

The association between PXF and glaucoma is well recognized. ${ }^{3,7}$ In fact, PXF has been described as the most common identifiable cause of open-angle glaucoma worldwide. ${ }^{8}$ Studies have also shown that glaucomatous damage progresses more rapidly in patients with PXF and glaucoma when compared with those having chronic open-angle glaucoma. ${ }^{9-14}$ Visual field defects have also been shown to be more severe at the time of diagnosis in patients with pseudoexfoliative glaucoma $(\mathrm{PXG})^{11,15}$ and to deteriorate more rapidly when compared with chronic open-angle glaucoma. ${ }^{16}$ Cataracts have been reported to be more common in PXF patients, ${ }^{17,18}$ and PXF has also been shown to be associated with zonulysis during cataract surgery as well as postoperative lens dislocation. ${ }^{8,19}$

PXF is an age-related disease with significant geographic and racial variations in prevalence. ${ }^{20-23}$ Population-based studies have reported prevalence rates of PXF worldwide varying from $0 \%{ }^{24}$ to over $40 \% .^{20,21,24}$ The prevalence of PXF has been reported in various parts of the world, including Europe, the Middle East, and Australia. ${ }^{25-41}$ 
Singapore is a multiracial country, comprising predominantly Chinese, Malay, and Indian populations. To date, there have only been two studies looking at the prevalence of PXF in the Singapore population, and both targeted specific ethnic groups. ${ }^{42,43}$ Therefore, this study was conducted to provide further insight into the demographics of PXF and PXG across all ethnic groups in Singapore.

\section{Materials and methods}

All patients aged 40 years or older seen by a single ophthalmologist over a period of 37 months (July 1, 2006, to July 31, 2009) at the general ophthalmology clinic of a tertiary hospital in Singapore were recruited into the study. Patients diagnosed with PXF were identified, and a retrospective case review of their case sheets was performed. Appropriate ethics approval was obtained from the National Healthcare Group Domain Specific Review Board.

All patients underwent a comprehensive ophthalmological assessment including visual acuity assessment, Goldmann applanation tonometry, slit-lamp examination before and after dilation of pupils, and dilated fundus examination. The anterior lens surface and pupillary ruff were inspected under high magnification. All eyes were also retroilluminated to detect the presence of a hoarfrost ring.

PXF was diagnosed if typical pseudoexfoliative material was present on the anterior lens capsule and/or pupillary margin in either one or both eyes. PXG was defined as the presence of typical pseudoexfoliative material in combination with a raised intraocular pressure of $>21 \mathrm{mmHg}$ and a reproducible visual field loss with optic disc cupping and neuroretinal rim thinning, with no evidence of other secondary causes of glaucoma.

The medical records of patients diagnosed with PXF and PXG were reviewed for demographic characteristics, including age, sex, and ethnic origin. Ethnic origin was ascertained based on the patients' registration information sheet.

All statistical analyses were performed using IBM SPSS Statistics (version 19, IBM Corp, Armonk, NY, USA) and $\mathrm{R}$ (version 2.15.2, The R Foundation for Statistical Computing, Vienna, Austria). The mean \pm standard deviation for age and frequencies of other demographic and clinical characteristics were calculated. The mean age was compared between groups using the independent-samples $t$-test, while categorical data, such as sex, race, and laterality, were compared using the Pearson chi-square test or Fisher's Exact test if expected counts within a category were less than 5 for more than $20 \%$ of cells. Logistic regression was performed
Table I Population with and without pseudoexfoliation syndrome based on age groups

\begin{tabular}{llll}
\hline $\begin{array}{l}\text { Age } \\
\text { (years) }\end{array}$ & $\begin{array}{l}\text { Non-PXF, } \\
\text { n (\%) }\end{array}$ & $\begin{array}{l}\text { PXF, } \\
\text { n (\%) }\end{array}$ & $\begin{array}{l}\text { All patients, } \\
\text { n (\%) }\end{array}$ \\
\hline $40-49$ & $340(10.6)$ & $\mathrm{I}(1.1)$ & $34 \mathrm{I}(10.3)$ \\
$50-59$ & $806(25.2)$ & $3(3.2)$ & $809(24.5)$ \\
$60-69$ & $984(30.7)$ & $32(34.4)$ & $\mathrm{I}, 016(30.8)$ \\
$70-79$ & $735(22.9)$ & $4 \mathrm{I}(44.1)$ & $776(23.5)$ \\
$\geq 80$ & $339(10.6)$ & $16(17.2)$ & $355(10.8)$ \\
Total & 3,204 & 93 & 3,297 \\
\hline
\end{tabular}

Abbreviation: PXF, pseudoexfoliation syndrome.

to calculate the odds ratio of likelihood of having PXF, with the $95 \%$ confidence interval (CI) for each demographic factor. A $P$-value of less than 0.05 was considered to indicate statistical significance.

\section{Results}

\section{Overall demographics}

A total of 3,297 patients were identified, of whom 1,459 $(44.3 \%)$ were male and 1,838 (55.7\%) were female. The ethnic distribution of the patients included 2,779 (84.3\%) Chinese, 199 (6.0\%) Malays, 237 (7.2\%) Indians, and 82 $(2.5 \%)$ from other races.

\section{Pseudoexfoliation syndrome}

Ninety-three patients $(2.8 \%, 146$ eyes) were identified as having PXF, of whom 46.2\% were male. PXF was bilateral in 53 patients $(57.0 \%)$. The mean age of patients with PXF was $72.2 \pm 8.7$ (range 44-94) years, with the majority $(95.7 \%$ ) being 60 years or older (Table 1). We found no significant sex predilection in the patients with PXF whether we analyzed the data as a cohort or in separate ethnic groups. The sex distribution of the patients with PXF according to ethnicity is summarized in Table 2.

The major ethnic groups among the 93 PXF patients were Chinese, Malay, and Indian (Table 3). In the Chinese population, $2.1 \%$ were found to have PXF. About twice the

Table 2 Sex distribution based on ethnicity in patients with pseudoexfoliation syndrome

\begin{tabular}{|c|c|c|c|}
\hline & \multicolumn{2}{|l|}{ Sex } & \multirow[t]{2}{*}{ Total } \\
\hline & Male & Female & \\
\hline \multicolumn{4}{|c|}{ Ethnicity n (\%) } \\
\hline Chinese & $22(5 \mid .2)$ & $36(72.0)$ & $58(62.4)$ \\
\hline Malay & $5(11.6)$ & $4(8.0)$ & $9(9.7)$ \\
\hline Indian & 15 (34.9) & $8(16.0)$ & $23(24.7)$ \\
\hline Others & I (2.3) & $2(4.0)$ & $3(3.2)$ \\
\hline Total & 43 & 50 & 93 \\
\hline
\end{tabular}


Table 3 Age, ethnicity, and sex of patients with pseudoexfoliation syndrome

\begin{tabular}{|c|c|c|c|c|c|c|c|c|}
\hline & $\begin{array}{l}\text { Non-PXF } \\
\text { population }\end{array}$ & $\begin{array}{l}\text { PXF } \\
\text { population }\end{array}$ & $\begin{array}{l}\text { Unadjusted } \\
\text { OR }\end{array}$ & $95 \% \mathrm{Cl}$ & $P$-value & $\begin{array}{l}\text { Adjusted OR } \\
\text { (full model) }\end{array}$ & $95 \% \mathrm{Cl}$ & $P$-value \\
\hline \multicolumn{9}{|l|}{ Age (years) } \\
\hline Mean \pm SD & $64.3 \pm 11.6$ & $72.2 \pm 8.7$ & 1.06 & $1.04-1.08$ & $<0.001$ & 1.07 & $1.05-1.09$ & $<0.001$ \\
\hline \multicolumn{9}{|l|}{ Ethnicity n (\%) } \\
\hline Chinese & $2,72 \mid(84.9)$ & $58(62.4)$ & Ref & - & - & Ref & - & - \\
\hline Malay & $190(5.9)$ & $9(9.7)$ & 2.22 & $1.08-4.55$ & 0.029 & 2.49 & $1.20-5.15$ & 0.014 \\
\hline Indian & $214(6.7)$ & $23(24.7)$ & 5.04 & $3.05-8.33$ & $<0.001$ & 6.00 & $3.57-10.09$ & $<0.001$ \\
\hline Others & $79(2.5)$ & $3(3.2)$ & 1.78 & $0.55-5.81$ & 0.338 & 1.71 & $0.5 I-5.67$ & $0.38 I$ \\
\hline \multicolumn{9}{|l|}{ Sex n (\%) } \\
\hline Female & I,788 (55.8) & $50(53.8)$ & Ref & - & - & Ref & - & - \\
\hline Male & $\mathrm{I}, 4 \mathrm{I} 6(44.2)$ & $43(46.2)$ & 1.09 & $0.72-1.64$ & 0.696 & 1.08 & $0.70-1.64$ & 0.734 \\
\hline
\end{tabular}

Abbreviations: $\mathrm{Cl}$, confidence interval; OR, odds ratio; SD, standard deviation; PXF, pseudoexfoliation syndrome; Ref, reference.

percentage of Malays (4.5\%) was found to have PXF. The Indian population were found to have the highest percentage of PXF (9.7\%) among the three major races.

Indians were found to be 5.04 times more likely to develop PXF than Chinese ( $P<0.001,95 \%$ CI 3.05-8.33), while Malays were 2.22 times more likely to develop PXF than Chinese ( $P=0.029$, 95\% CI 1.08-4.55). The relationship between sex and likelihood of developing PXF was not statistically significant $(P=0.696)$. The results were similar in the full model (Table 3). Our study found no statistically significant relationship between laterality and age, sex, or ethnicity (Table 4).

\section{Pseudoexfoliative glaucoma}

Of the 93 patients with PXF, 22 (23.7\%) were identified as having $\mathrm{PXG}$, among whom almost three quarters of cases were bilateral (16 patients, 72.7\%). The mean age of patients with PXG was $73.1 \pm 9.1$ years. There was no statistically significant difference in mean age between patients with PXG and those with PXF only ( $P=0.390$; Table 5). Eighteen $(81.8 \%)$ of the 22 patients were male. There was

Table 4 Association of laterality with age, sex, and ethnicity of patients in PXF population

\begin{tabular}{llll}
\hline & Unilateral & Bilateral & P-value \\
\hline $\begin{array}{l}\text { Patients, n (\%) } \\
\text { Age (years) } \\
\text { Mean } \pm \text { SD }\end{array}$ & $40(43.0)$ & $53(57.0)$ & \\
$\begin{array}{l}\text { Ethnicity n (\%) } \\
\text { Chinese }\end{array}$ & $70.9 \pm 7.9$ & $73.1 \pm 9.1$ & $0.237^{*}$ \\
Malay & $26(65.0)$ & $32(60.4)$ & $0.937^{* * *}$ \\
Indian & $3(7.5)$ & $6(1 \mathrm{I} .3)$ & \\
Others & $10(25.0)$ & $13(24.5)$ & \\
Sex, n (\%) & $\mathrm{I}(2.5)$ & $2(3.8)$ & $0.530^{* * *}$ \\
Male & $17(42.5)$ & $26(49.1)$ & \\
Female & $23(57.5)$ & $27(50.9)$ & \\
\hline
\end{tabular}

Notes: *Independent samples $t$-test; **Pearson chi-square test; ****Fisher's Exact test. Abbreviations: SD, standard deviation; PXF, pseudoexfoliation syndrome. a significantly larger proportion of males with PXG than without PXG $(P<0.001$; Table 5).

The ethnic distribution of the patients with PXG included 12 Chinese (55.5\%), three Malays (13.6\%), and seven Indians $(31.8 \%)$. There was no statistically significant difference in ethnic distribution of PXG patients when compared with non-PXG patients $(P=0.531$, Table 5). Subgroup analysis also revealed no sex predilection in the various ethnic groups. Our study found a larger proportion of bilateral eye involvement of PXF in the PXG group when compared with the non-PXG group, although the difference did not reach statistical significance $(P=0.088)$.

\section{Discussion}

PXF has been shown in previous studies to be associated with increasing age, typically being more common after the age of 60 years. Forsius et $\mathrm{al}^{20}$ found that the incidence of PXF doubled every decade after the age of 50 years. Our study observed a similar trend. However, we also observed a decrease in the number of patients with PXF from the age of 80 years onwards. There are two possible explanations for this observation. The average life expectancy of

Table 5 Age, ethnicity, and sex of PXG patients

\begin{tabular}{lll}
\hline & $\begin{array}{l}\text { Non-PXG } \\
\text { population }\end{array}$ & $\begin{array}{l}\text { PXG } \\
\text { population }\end{array}$ \\
\hline $\begin{array}{l}\text { Age (years) } \\
\text { Mean } \pm \text { SD } \\
\text { Ethnicity n (\%) } \\
\text { Chinese }\end{array}$ & $70.9 \pm 7.9$ & $73.1 \pm 9.1$ \\
Malay & $46(64.8)$ & $12(54.5)$ \\
Indian & $6(8.5)$ & $3(13.6)$ \\
Others & $16(22.5)$ & $7(31.8)$ \\
Sex, n (\%) & $3(4.2)$ & $0(0.0)$ \\
Female & & $4(18.2)$ \\
Male & $46(64.8)$ & $18(8 \mid .8)$ \\
\hline
\end{tabular}

Abbreviations: PXG, pseudoexfoliative glaucoma; SD, standard deviation. 
Singapore's population around the time of data collection was 81.4 years, ${ }^{44}$ so the decrease in numbers of patients aged over 80 years could be attributed to a higher death rate in that age group. Another possible explanation could be that more people over 80 years of age are pseudophakic, and mild underlying PXF may have been undetected after surgery. Various studies have shown conflicting results for sex predisposition. ${ }^{25,28,40,45}$ However, our present study found no significant sex predilection.

The prevalence of PXF has been shown to vary significantly between populations $7,25,26,28-30,32-37,39-43,45-55$ (Table 6). The underlying reason for the large demographic variation in PXF is still undetermined. However, factors including genetics $^{56-58}$ and environmental influences such as living in lower latitudes, ${ }^{21}$ sun exposure, ${ }^{20,46}$ dietary factors, ${ }^{50}$ altitude,${ }^{53}$ and even iris color ${ }^{59}$ have been postulated.

Data from previous studies have shown that the prevalence of PXF in East Asians is low when compared with Europeans..$^{25,28,29,40-43}$ It has been postulated that this may be

Table 6 Prevalence of PXF in populations around the world

\begin{tabular}{|c|c|c|}
\hline Country & Age (years) & Prevalence (\%) \\
\hline Australia (Central Australia) ${ }^{46}$ & $\geq 61$ & 16.3 \\
\hline Australia (Blue Mountains) ${ }^{7}$ & $49-97$ & 2.3 \\
\hline Australia (Victoria) $)^{33}$ & $\geq 40$ & 0.98 \\
\hline People's Republic of China ${ }^{41}$ & $\geq 50$ & 2.38 \\
\hline Finland ${ }^{17}$ & $\geq 70$ & 22.1 \\
\hline France $^{49}$ & $>50$ & 5.5 \\
\hline Greece (Epirus) $)^{51}$ & $\geq 50$ & 24.3 \\
\hline Greece $(\text { Crete })^{53}$ & $\geq 40$ & 16.1 \\
\hline Greenland ${ }^{50}$ & $\geq 70$ & 4.5 \\
\hline Hong Kong ${ }^{45}$ & $\geq 60$ & 0.4 \\
\hline Iceland ${ }^{28}$ & $\geq 50$ & 10.7 \\
\hline India (South India) ${ }^{29}$ & $\geq 40$ & 3.8 \\
\hline India $(\text { Tamil Nadu })^{32}$ & $\geq 40$ & 6.0 \\
\hline India (Andhra Pradesh) ${ }^{40}$ & $\geq 40$ & 3.01 \\
\hline India (Central India) $)^{55}$ & $\geq 30$ & 0.95 \\
\hline $\operatorname{Iran}^{35}$ & $\geq 50$ & 13.1 \\
\hline$J_{a p a n}^{34}$ & $\geq 50$ & 3.4 \\
\hline Jordan ${ }^{26}$ & $40-90$ & 9.1 \\
\hline Myanmar ${ }^{25}$ & $\geq 40$ & 3.4 \\
\hline Nepal (Gurungs) ${ }^{37}$ & $\geq 30$ & 8.2 \\
\hline Nepal (Tamangs) $)^{37}$ & $\geq 30$ & 0.3 \\
\hline Nigeria $^{54}$ & $30-90$ & 2.7 \\
\hline Norway ${ }^{48}$ & $>65$ & 16.9 \\
\hline Pakistan $^{36}$ & $\geq 45$ & 6.45 \\
\hline Singapore (Chinese $)^{42}$ & $\geq 40$ & 0.2 \\
\hline Singapore (Malay) $)^{43}$ & $40-80$ & 0.46 \\
\hline Turkey $^{52}$ & $\geq 50$ & 7.2 \\
\hline USA (Framingham) ${ }^{47}$ & $52-85$ & 1.8 \\
\hline USA (Southeastern USA) ) $^{30}$ & $\geq 60$ & 3.2 \\
\hline
\end{tabular}

Notes: Current study: Chinese 2.I\%; Malays 4.5\%; Indians $9.7 \%$. Abbreviation: PXF, pseudoexfoliation syndrome. the result of both genetic composition and environmental influences.

PXF has been described as being rare in the Chinese population. Lee et $\mathrm{al}^{60}$ showed that the $\mathrm{G}$ allele of rs 3825942 within LOXL1 confers a tenfold increase in risk for $\mathrm{PXF} / \mathrm{PXG}$ in the Chinese population. However, they found a similar allelic architecture between Chinese and other Caucasian populations, and went on to postulate that there might be other genetic and/or strong environmental factors that could be modulating the phenotypic expression of PXF in the Chinese population, resulting in a lower prevalence of the disease.

In this study, we observed that approximately $2.1 \%$ of the Chinese population had PXF. This value was similar to that reported by the Beijing Eye Study, ${ }^{41}$ which found an overall prevalence of definite PXF in a Northern Chinese population of $2.38 \%$, but this is much higher than that reported by the Tanjong Pagar survey ${ }^{42}$ or a hospital-based cohort study in Hong Kong. The Tanjong Pagar survey looked specifically at Chinese Singaporean adults aged 40 years and older and observed a prevalence of $0.2 \%$ that rose to $0.7 \%$ in those over 60 years of age. Young et $\mathrm{al}^{45}$ investigated a hospital-based cohort of Chinese in Hong Kong and observed a prevalence of $0.4 \%$.

In our study, $9.7 \%$ of Indians were found to have PXF. Krishnadas et al, ${ }^{32}$ Arvind et $\mathrm{al}^{29}$ and Thomas et $\mathrm{al}^{40}$ looked at the South Indian populations and reported prevalences of $6.0 \%, 3.8 \%$, and $3.01 \%$, respectively, in individuals over the age of 40 years. Jonas et $\mathrm{al}^{55}$ looked at Central Indian populations aged 30 and above and reported the prevalence of PXF to be $0.95 \%$.

Data on the prevalence of pseudoexfoliation in the Malay ethnic group is very limited. The Singapore Malay Eye Study ${ }^{43}$ is the only research that has looked at the prevalence of PXF in the Malay population aged 40-80 years, and reported the prevalence of PXF in Malays to be $0.46 \%$. Our study observed a much higher percentage, with $4.5 \%$ of Malays having PXF.

The higher proportion of PXF found in all ethnic groups in our study could be attributed to the fact that our research was hospital-based. PXF has been described to be more prevalent in patients with ocular conditions such as cataracts and glaucoma, ${ }^{3}$ and determining prevalence in a hospital-based cohort would have resulted in some degree of selection bias.

Another explanation could be that the prevalence of PXF is in fact higher in the general population and that we may be underdiagnosing the condition. Making a diagnosis of 
PXF requires a careful slit-lamp examination ${ }^{3}$ after pupillary dilatation, and the condition may be underdiagnosed in the community.

When comparing the three ethnic groups in our present study, we observed that Indians were five times more likely to have PXF than Chinese, whereas Malays were about twice as likely to have PXF when compared with Chinese. This is consistent with the available data on the prevalence of PXF in these three races. ${ }^{29,32,40,42,43,45}$

Almost one in four (23.6\%) PXF patients in our study had glaucoma. Studies that have looked at PXG in PXF patients have reported variable percentages. The Andhra Pradesh Eye Disease study ${ }^{40}$ reported that $5.5 \%$ of PXF patients had glaucoma. In the Aravind Comprehensive Eye Survey, ${ }^{32}$ $23(7.5 \%)$ of 308 patients had definite glaucoma, while the Blue Mountain Eye Study ${ }^{7}$ reported a 14.2\% incidence of glaucoma. A possible explanation for this variation in the percentage of glaucoma could be due to genetic as well as environmental differences. Previously mentioned studies had focused on Indian or Caucasian populations; our present study, however, focused on a predominantly Chinese population in a hospital clinic setting where ocular diseases are expected to be encountered more frequently. Our study also found a significantly larger proportion of males than female with PXG. Nevertheless, the reliability of this finding may be limited given the small sample size.

Our current study is one of the largest of its kind to address PXF among the Chinese and Malay populations living in Southeast Asia. It is also the first study to make direct comparisons between PXF sufferers in the Chinese, Malay, and Indian populations within the unique multiracial setting of Singapore. There was also consistency in clinical examinations, as all were performed by the same ophthalmologist.

The limitations of the present study include its retrospective design, and its hospital-based nature, which may have possibly resulted in selection bias. A larger prospective study looking at the prevalence of PXF in the local community would be helpful to decipher the unique epidemiology of PXF in our local population. In conclusion, PXF is not infrequently encountered in elderly Singapore eye clinic patients, and is more likely to occur in Indians and less likely in Chinese. In the Singapore clinic setting, males may be more likely to develop PXG, although larger studies will be required to confirm this.

\section{Acknowledgment}

The authors would like to thank Dr Rupesh Agrawal for his advice regarding the writing of this article.

\section{Disclosure}

The authors report no conflicts of interest in this work.

\section{References}

1. Naumann GO, Schlotzer-Schrehardt U, Kuchle M. Pseudoexfoliation syndrome for the comprehensive ophthalmologist. Intraocular and systemic manifestations. Ophthalmology. 1998;105(6):951-968.

2. Netland PA, Ye H, Streeten BW, Hernandez MR. Elastosis of the lamina cribrosa in pseudoexfoliation syndrome with glaucoma. Ophthalmology. 1995;102(6):878-886.

3. Ritch R, Schlotzer-Schrehardt U. Exfoliation syndrome. Surv Ophthalmol. 2001;45(4):265-315.

4. Schlotzer-Schrehardt U, von der Mark K, Sakai LY, Naumann GO. Increased extracellular deposition of fibrillin-containing fibrils in pseudoexfoliation syndrome. Invest Ophthalmol Vis Sci. 1997;38(5): 970-984.

5. Schlotzer-Schrehardt UM, Koca MR, Naumann GO, Volkholz H. Pseudoexfoliation syndrome. Ocular manifestation of a systemic disorder? Arch Ophthalmol. 1992;110(12):1752-1756.

6. Ritch R. Exfoliation syndrome. Curr Opin Ophthalmol. 2001;12(2): 124-130.

7. Mitchell P, Wang JJ, Hourihan F. The relationship between glaucoma and pseudoexfoliation: the Blue Mountains Eye Study. Arch Ophthalmol. 1999;117(10):1319-1324.

8. Ritch R. Exfoliation syndrome - the most common identifiable cause of open-angle glaucoma. J Glaucoma. 1994;3(2):176-177.

9. Aasved $\mathrm{H}$. The frequency of optic nerve damage and surgical treatment in chronic simple glaucoma and capsular glaucoma. Acta Ophthalmol (Copenh). 1971;49(4):589-600.

10. Futa R, Shimizu T, Furuyoshi N, Nishiyama M, Hagihara O. Clinical features of capsular glaucoma in comparison with primary openangle glaucoma in Japan. Acta Ophthalmol (Copenh). 1992;70(2): 214-219.

11. Lindblom B, Thorburn W. Prevalence of visual field defects due to capsular and simple glaucoma in Halsingland, Sweden. Acta Ophthalmol (Copenh). 1982;60(3):353-361.

12. Lindblom $B$, Thorburn W. Functional damage at diagnosis of primary open angle glaucoma. Acta Ophthalmol (Copenh). 1984;62(2):223-229.

13. Moreno-Montanes J, Alvarez Serna A, Alcolea Paredes A. Pseudoexfoliative glaucoma in patients with open-angle glaucoma in the northwest of Spain. Acta Ophthalmol (Copenh). 1990;68(6):695-699.

14. Tarkkanen A. Treatment of chronic open-angle glaucoma associated with pseudoexfoliation. Acta Ophthalmol (Copenh). 1965;43(4): 514-523.

15. Konstas AG, Stewart WC, Stroman GA, Sine CS. Clinical presentation and initial treatment patterns in patients with exfoliation glaucoma versus primary open-angle glaucoma. Ophthalmic Surg Lasers. 1997;28(2): 111-117.

16. Olivius E, Thorburn W. Prognosis of glaucoma simplex and glaucoma capsulare. A comparative study. Acta Ophthalmol (Copenh). 1978;56(6):921-934.

17. Hirvela H, Luukinen H, Laatikainen L. Prevalence and risk factors of lens opacities in the elderly in Finland. A population-based study. Ophthalmology. 1995;102(1):108-117.

18. Rouhiainen H, Terasvirta M. Presence of pseudoexfoliation on clear and opacified crystalline lenses in an aged population. Ophthalmologica. 1992;204(2):67-70.

19. Belovay GW, Varma DK, Ahmed, II. Cataract surgery in pseudoexfoliation syndrome. Curr Opin Ophthalmol. 2010;21(1):25-34.

20. Forsius H. Exfoliation syndrome in various ethnic populations. Acta Ophthalmol Suppl. 1988;184:71-85.

21. Ringvold A. Epidemiology of the pseudo-exfoliation syndrome. Acta Ophthalmol Scand. 1999;77(4):371-375.

22. Dell WM. The epidemiology of the pseudo-exfoliation syndrome. J Am Optom Assoc. 1985;56(2):113-119. 
23. Dickson DH, Ramsey MS. Symposium on pseudocapsular exfoliation and glaucoma. Fibrillopathia epitheliocapsularis: review of the nature and origin of pseudoexfoliative deposits. Trans Ophthalmol Soc UK. 1979;99(2): 284-292.

24. Forsius H. Prevalence of pseudoexfoliation of the lens in Finns, Lapps, Icelanders, Eskimos, and Russians. Trans Ophthalmol Soc UK. 1979;99(2):296-298.

25. Abdul-Rahman AM, Casson RJ, Newland HS, et al. Pseudoexfoliation in a rural Burmese population: the Meiktila Eye Study. Br J Ophthalmol. 2008;92(10):1325-1328.

26. Al-Bdour MD, Al-Till MI, Idrees GM, Abu Samra KM. Pseudoexfoliation syndrome at Jordan University Hospital. Acta Ophthalmol. 2008;86(7):755-757.

27. Andrikopoulos GK, Mela EK, Georgakopoulos CD, et al. Pseudoexfoliation syndrome prevalence in Greek patients with cataract and its association to glaucoma and coronary artery disease. Eye (Lond). 2009;23(2):442-447.

28. Arnarsson A, Damji KF, Sverrisson T, Sasaki H, Jonasson F. Pseudoexfoliation in the Reykjavik Eye Study: prevalence and related ophthalmological variables. Acta Ophthalmol Scand. 2007;85(8):822-827.

29. Arvind H, Raju P, Paul PG, et al. Pseudoexfoliation in South India. Br J Ophthalmol. 2003;87(11):1321-1323.

30. Cashwell LF Jr, Shields MB. Exfoliation syndrome. Prevalence in a southeastern United States population. Arch Ophthalmol. 1988;106(3): 335-336.

31. Karger RA, Jeng SM, Johnson DH, Hodge DO, Good MS. Estimated incidence of pseudoexfoliation syndrome and pseudoexfoliation glaucoma in Olmsted County, Minnesota. J Glaucoma. 2003;12(3): 193-197.

32. Krishnadas R, Nirmalan PK, Ramakrishnan R, et al. Pseudoexfoliation in a rural population of southern India: the Aravind Comprehensive Eye Survey. Am J Ophthalmol. 2003;135(6):830-837.

33. McCarty CA, Taylor HR. Pseudoexfoliation syndrome in Australian adults. Am J Ophthalmol. 2000;129(5):629-633.

34. Miyazaki M, Kubota T, Kubo M, et al. The prevalence of pseudoexfoliation syndrome in a Japanese population: the Hisayama study. J Glaucoma. 2005;14(6):482-484.

35. Nouri-Mahdavi K, Nosrat N, Sahebghalam R, Jahanmard M. Pseudoexfoliation syndrome in central Iran: a population-based survey. Acta Ophthalmol Scand. 1999;77(5):581-584.

36. Rao RQ, Arain TM, Ahad MA. The prevalence of pseudoexfoliation syndrome in Pakistan. Hospital based study. BMC Ophthalmol. 2006;6:27.

37. Shakya S, Dulal S, Maharjan IM. Pseudoexfoliation syndrome in various ethnic population of Nepal. Nepal Med Coll J. 2008;10(3):147-150.

38. Shimizu K, Kimura Y, Aoki K. Prevalence of exfoliation syndrome in the Japanese. Acta Ophthalmol Suppl. 1988;184:112-115.

39. Summanen P, Tonjum AM. Exfoliation syndrome among Saudis. Acta Ophthalmol Suppl. 1988;184:107-111.

40. Thomas R, Nirmalan PK, Krishnaiah S. Pseudoexfoliation in southern India: the Andhra Pradesh Eye Disease Study. Invest Ophthalmol Vis Sci. 2005;46(4):1170-1176.

41. You QS, Xu L, Wang YX, et al. Pseudoexfoliation: normative data and associations. The Beijing Eye Study 2011. Ophthalmology. 2013; 120(8):1551-1558.

42. Foster PJ, Seah SK. The prevalence of pseudoexfoliation syndrome in Chinese people: the Tanjong Pagar Survey. Br J Ophthalmol. 2005; 89(2):239-240.

Clinical Ophthalmology

\section{Publish your work in this journal}

Clinical Ophthalmology is an international, peer-reviewed journal covering all subspecialties within ophthalmology. Key topics include: Optometry; Visual science; Pharmacology and drug therapy in eye diseases; Basic Sciences; Primary and Secondary eye care; Patient Safety and Quality of Care Improvements. This journal is indexed on Submit your manuscript here: http://www.dovepress.com/clinical-ophthalmology-journal
43. Sumasri K, Raju P, Aung T, Wong TY. Prevalence of pseudoexfoliation in Malay population in Singapore. Am J Ophthalmol. 2008;145(4): 766-767.

44. Singapore Statistics. Complete life tables 2013-2014 for Singapore resident population. Available from: http:/www.singstat.gov.sg/docs/ default-source/default-document-library/publications/publications_ and_papers/births_and_deaths/lifetable13-14.pdf. Accessed June 28, 2015.

45. Young AL, Tang WW, Lam DS. The prevalence of pseudoexfoliation syndrome in Chinese people. Br J Ophthalmol. 2004;88(2): 193-195.

46. Taylor HR, Hollows FC, Moran D. Pseudoexfoliation of the lens in Australian Aborigines. Br J Ophthalmol. 1977;61(7):473-475.

47. Hiller R, Sperduto RD, Krueger DE. Pseudoexfoliation, intraocular pressure, and senile lens changes in a population-based survey. Arch Ophthalmol. 1982;100(7):1080-1082.

48. Ringvold A, Blika S, Elsas T, et al. The prevalence of pseudoexfoliation in three separate municipalities of Middle-Norway. A preliminary report. Acta Ophthalmol Suppl. 1987;182:17-20.

49. Colin J, Le Gall G, Le Jeune B, Cambrai MD. The prevalence of exfoliation syndrome in different areas of France. Acta Ophthalmol Suppl. 1988;184:86-89.

50. Ostenfeld-Akerblom A. Pseudoexfoliation in Eskimos (Inuit) in Greenland. Acta Ophthalmol (Copenh). 1988;66(4):467-468.

51. Stefaniotou M, Petroutsos G, Psilas K. The frequency of pseudoexfoliation in a region of Greece (Epirus). Acta Ophthalmol (Copenh). 1990;68(3):307-309.

52. Yalaz M, Othman I, Nas K, et al. The frequency of pseudoexfoliation syndrome in the eastern Mediterranean area of Turkey. Acta Ophthalmol (Copenh). 1992;70(2):209-213.

53. Kozobolis VP, Papatzanaki M, Vlachonikolis IG, Pallikaris IG, Tsambarlakis IG. Epidemiology of pseudoexfoliation in the island of Crete (Greece). Acta Ophthalmol Scand. 1997;75(6):726-729.

54. Olawoye OO, Ashaye AO, Teng CC, Liebmann JM, Ritch R, Ajayi BG. Exfoliation syndrome in Nigeria. Middle East Afr J Ophthalmol. 2012; 19(4):402-405.

55. Jonas JB, Nangia V, Matin A, et al. Pseudoexfoliation: normative data and associations. The Central India Eye and Medical Study. PLoS One. 2013;8(10):e76770.

56. Anastasopoulos E, Coleman AL, Wilson MR, et al. Association of LOXL1 polymorphisms with pseudoexfoliation, glaucoma, intraocular pressure, and systemic diseases in a Greek population. The Thessaloniki eye study. Invest Ophthalmol Vis Sci. 2014;55(7):4238-4243.

57. Anastasopoulos E, Founti P, Topouzis F. Update on pseudoexfoliation syndrome pathogenesis and associations with intraocular pressure, glaucoma and systemic diseases. Curr Opin Ophthalmol. 2015; 26(2):82-89.

58. Schlotzer-Schrehardt U, Pasutto F, Sommer P, et al. Genotype-correlated expression of lysyl oxidase-like 1 in ocular tissues of patients with pseudoexfoliation syndrome/glaucoma and normal patients. Am J Pathol. 2008;173(6):1724-1735.

59. Konstas AG, Dimitrakoulias N, Kourtzidou O, Filidis K, Bufidis T, Benos A. Frequency of exfoliation syndrome in Greek cataract patients. Acta Ophthalmol Scand. 1996;74(5):478-482.

60. Lee KY, Ho SL, Thalamuthu A, et al. Association of LOXL1 polymorphisms with pseudoexfoliation in the Chinese. Mol Vis. 2009; 15:1120-1126.

\section{Dovepress}

PubMed Central and CAS, and is the official journal of The Society of Clinical Ophthalmology (SCO). The manuscript management system is completely online and includes a very quick and fair peer-review system, which is all easy to use. Visit http://www.dovepress.com/ testimonials.php to read real quotes from published authors. 